\title{
Controvérsias e a Produção do Transnacional: Os Casos da Contag e do MPA
}

\author{
Priscila Delgado de Carvalho ${ }^{1}$ \\ Pesquisadora em estágio pós-doutoral no Instituto da Democracia e da Democratização da Comunicação \\ (INCT-IDDC). Belo Horizonte, MG. Brasil. \\ E-mail: prisciladcarvalho@gmail.com.
}

\section{INTRODUÇÃO}

Ce as primeiras análises sobre a globalização previam a dissolução $\checkmark$ das fronteiras, identidades e territórios nacionais e a crescente substituição de governos nacionais por organismos globais, rapidamente surgiram outras leituras destacando o aumento de interdependências econômicas e culturais entre países, empresas e pessoas. Estados e territórios nacionais permaneceram como referentes políticos, ainda que agora atravessados por outras relações. Ao menos parcialmente, o global habita o nacional e vice-versa (Sassen, 2007). Compreender a maneira como tais interseções ocorrem gera desafios teóricos e metodológicos às ciências sociais e demanda ferramentas capazes de dar conta de sua complexidade. Propostas teóricas recentes questionam a metáfora das escalas e propõem, em seu lugar, a das conexões: mais global é o mais conectado, não o que está mais distante do local, do território, ou mais no alto (Latour, 2008).

Estudos sobre ativismo e movimentos sociais transnacionais contribuíram para tornar mais complexas as narrativas acerca dos impactos de processos globais. Ativistas empreenderam esforços de resistência aos fluxos globais, mas também construíram redes de apoio e intercâmbios (Tarrow, 2005). Análises sobre o feminismo transnacional estiveram entre as primeiras que identificaram alianças entre pessoas e coletivos que se valeram da possibilidade de atuação conjunta para questionar os Estados, os organismos internacionais, e diversas práticas instauradas nas sociedades nacionais (Alvarez, 2000; Desai, 2009; Thayer, 2010). Emerge dos olhares sobre a transnacionalização dos feminismos 
uma definição de transnacionalização como o emprego de práticas e discursos inspiradas pelo engajamento das ativistas com atores para além das fronteiras nacionais (Alvarez, 2000).

Este artigo parte de uma leitura de dois processos de transnacionalização baseada nas controvérsias em que atores coletivos se engajaram. Revisita a definição de Alvarez (2000) sugerindo ser necessário, para que haja transnacionalização, que os grupos estabeleçam disputas ou modifiquem disputas existentes, contribuindo para transformar em questões públicas temas que de outro modo estariam estabilizados.

Em várias partes do mundo os camponeses e camponesas, contrariando a associação ao tradicional, ao não moderno ou à passividade, constroem ações de cooperação, de contestação e de protestos por meio de alianças que sobrepõem origens nacionais (Borras Jr. e Edelman, 2016; Desmarais, 2007; Pleyers, 2010). No Brasil, a população rural - cerca de 16\% dos habitantes (IBGE, 2010) - se engaja em debates e disputas, que perpassam conexões transnacionais, por meio de suas organizações.

Ainda nos anos 1990, o Movimento dos Trabalhadores Rurais Sem-Terra (MST) fez parte da criação da Via Campesina, que impactou os debates internacionais sobre alimentação ao questionar o conceito de segurança alimentar e propor a noção de soberania alimentar (Desmarais, 2007). Além de contribuir para estabelecer essas disputas, o MST realiza ações de cooperação (como cursos de formação política para movimentos de outros países) e participa de brigadas internacionalistas em países como Haiti (Bringel e Vieira, 2015), Moçambique e África do Sul. Na última década, camponeses e camponesas do Movimento dos Pequenos Agricultores (MPA) foram a Moçambique, ao Paraguai e à Venezuela para compartilhar técnicas de multiplicação e conservação de sementes crioulas. Ao lado de aliados internacionais, ativistas brasileiros discutem como a produção de alimentos é parte de cadeias globais de comércio e questionam impactos de acordos comerciais sobre preços de produtos e modos de vida. Desde 2003, lideranças sindicais rurais brasileiras ligadas à Confederação Nacional dos Trabalhadores na Agricultura (Contag) participam semestralmente de reuniões do Mercado Comum do Sul (Mercosul) que contribuem com a difusão, nos países do bloco, da ideia de que devem existir políticas públicas específicas voltadas para a agricultura familiar. 
Neste artigo é analisada a construção de articulações transnacionais por atores rurais brasileiros. Para tanto, foca-se na ação transnacional do MPA e da Contag. Os casos selecionados compartilham resultados (a transnacionalização), mas diferem nos percursos (período de origem, aliados internacionais, questões e espaços priorizados). Pesquisas sobre o ativismo transnacional da Contag e do MPA são raras, ainda que haja referência a eles em trabalhos recentes (Niemeyer, 2014; Carvalho, 2020). Essa seleção justifica-se tanto pela relevância política da Contag e do MPA, quanto pela relevância de compreender a diversidade de processos de transnacionalização de coletivos rurais no país. Os casos mostram variações no interior das organizações de trabalhadores rurais brasileiros e diversificam as narrativas disponíveis sobre eles, uma vez que os estudos dessa área se concentram majoritariamente no MST (Bringel, 2010; Bringel e Falero, 2008; Rubbo, 2013).

A centralidade conferida pela academia brasileira ao MST reflete sua importância política, posto que esse movimento reconfigurou a gramática da relação entre trabalhadores sem-terra e o Estado, e inspirou diversos outros grupos no Brasil e no exterior (Borras e Edelman, 2016; Rosa, 2010). Sua relevância também indica certa tendência, na academia, de atentar para os grupos mais evidentes, destinando pouca atenção a outros processos igualmente relevantes.

Durante o período colonial, a população rural reagiu à violência imposta pela metrópole, individual ou coletivamente. A reação ocorria por meio de fugas, insurreições e rebeliões de escravos, indígenas e de colonos. Na República Velha, populações rurais protagonizaram revoltas como as de Canudos e a do Contestado. Trataram-se, porém, de iniciativas localizadas até meados do século XX, quando passaram a ter caráter articulado com outras forças políticas - via partidos comunistas ou socialistas, e pela formação das Ligas Camponesas (Fernandes, Medeiros e Paulilo, 2009). Desde então, ganharam vez os sindicatos rurais (Medeiros, 1989; Welch, 2010) e, a partir dos anos 1980, movimentos sociais (Carter, 2010; Fernandes, 2010; Sigaud, Ernandez e Rosa, 2010) - que, muitas vezes, influenciavam-se mutuamente (Rosa, 2010).

A Contag, fundada em 1963, foi a primeira confederação sindical de trabalhadores rurais no Brasil. Composta por federações em todos os estados brasileiros, representou até 2015 tanto trabalhadores assalariados, permanentes ou temporários, quanto aqueles em regime familiar, com terra própria, arrendada etc. (Medeiros, 2014) ${ }^{1}$. Esteve à frente de 
debates sobre reforma agrária, previdência social e política agrícola; e sobreviveu à ditadura militar, instalada pouco após sua criação, reivindicando direitos para a população rural com base na legislação trabalhista disponível. Envolveu-se nos debates agrários da Constituinte e precisou reformular suas práticas em resposta à transformação dos atores rurais nos anos 1980 e 1990, quando voltou a promover ações de massa (Favareto, 2006; Medeiros, 1989, 1997, 2014; Ricci, 1999 e 2009; Tavares, 1992). No final dos 1990 incorporou a agricultura familiar como categoria de identificação e passou a defendê-la como modelo de produção agrícola (Picolotto, 2015). Mais tarde, esse debate foi levado ao Mercosul por meio da Confederação de Organizações de Produtores Familiares do Mercosul (Coprofam), para cuja criação a Contag foi central. Aos poucos, mulheres e jovens foram conquistando espaços no sindicalismo rural (Abramovay e Silva, 2000). Esses segmentos construíram alianças internacionais no Mercosul e em redes como o Fórum Rural Mundial.

O MPA foi fundado em 1996 e atualmente está presente em cerca de 17 estados brasileiros. Sua criação expressou divergências com a forma de atuação dos sindicatos rurais vinculados à Contag e à Central Única dos Trabalhadores (CUT), e até hoje membros do MPA dirigem alguns sindicatos rurais. Expressou também articulações com a Comissão Pastoral da Terra (CPT) e com o MST. O MPA ficou conhecido pela ênfase em políticas de crédito (Rosa, 2010). Porém, desde sua fundação, demanda também políticas capazes de melhorar a vida no campo (como programas de habitação) e envolveu-se em debates e propostas sobre políticas agrícolas (Cadoná, 2004; Costa, 2014; Tavares, Costa e Fagundes, 2016). Em 2003, o MPA reformulou seu projeto político, incluindo o conceito de soberania alimentar, e passou a se apresentar como um movimento de camponeses, aproximando-se e filiando-se à Via Campesina e empreendendo debates próprios sobre o significado do termo (Carvalho, 2020).

As categorias de identificação usadas por cada movimento os conectam a um extenso debate sobre como reunir e diferenciar trabalhadores rurais, agricultores familiares, parceiros, arrendatários, camponeses, lavradores e pequenos produtores. Nos anos 1960, o sindicalismo agregou-os sob a denominação de trabalhadores rurais (Medeiros, 2014; Palmeira, 1985). O termo camponês, que faz parte da tradição de esquerda, foi retomado pelo MPA como uma forma de vida específica que orienta relações com a terra e o mercado, em diálogo com ativistas 
da Via Campesina e pesquisadores (Sevilla Guzmán e Molina, 2013). Agricultura familiar ganhou força nos anos 1990, em uma conjunção entre academia, atores estatais e sindicalismo, estabelecendo-se como referencial positivo e capaz de orientar políticas específicas e diferenciadas para agricultores - como acesso ao crédito e à assistência técnica (Picolotto, 2015). Logo, porém, foram destacados os pontos de ruptura e continuidade entre as categorias agricultor familiar e campesinato (Wanderley, 2003). Com a criação do Programa Nacional de Fortalecimento da Agricultura Familiar (Pronaf), em 1996, delimitou-se formalmente a agricultura familiar segundo critérios relativos ao uso de mão de obra, área das propriedades e renda. A partir daí o conceito passou a, de fato, orientar políticas públicas no país (Bergamasco e Delgado, 2017). As diferenças econômicas e de práticas agrícolas entre agricultores familiares e camponeses são relevantes; porém, não é simples traçar uma linha separando esses perfis, uma vez que são atravessadas também por questões econômicas, culturais e pelas trajetórias das lideranças e das organizações nos estados e municípios. A este artigo interessa especialmente entender como essas categorias foram empregadas politicamente e de forma relacional, e como foram mobilizadas e reconfiguradas nos debates e alianças transnacionais.

Nas páginas a seguir, os processos de transnacionalização da Contag e do MPA são analisados a partir das controvérsias nas quais se engajaram, argumentando serem ferramentas úteis para enfrentar os desafios colocados às interações contemporâneas que envolvem diversas fronteiras e escalas. Controvérsias são disputas nas quais atores se envolvem e por meio das quais ficam visíveis as conexões e associações que estabelecem (Latour, 2008). Trata-se de questões marcadas por desentendimentos e incertezas: pautas ainda não estabilizadas, cujos sentidos e composições estão em disputa (Latour, 2008; Law, 2004; Venturini, 2010). Não se tratam, assim, de disputas entre os grupos aqui estudados, mas de questões nas quais cada um deles se envolveu ou ajudou a estabelecer. Nelas, tornam-se visíveis as conexões estabelecidas pelos grupos em sua ação, dado que ao se posicionar precisam dizer o que pensam, com quem conversam e a que grupos se aliam ou se opõem. Disputas também são momentos propícios para que novas conexões (ou associações) sejam estabelecidas (Latour, 2008) . O uso dessa abordagem para análise de movimentos sociais e suas interações segue a trilha estabelecida por Rodríguez-Giralt (2011) e, no Brasil, por Fleury (2014) , Penna (2015) e Rosa (2015). 
Metodologicamente, foram identificadas conexões da Contag e do MPA com atores e temas transnacionais por meio da análise dos documentos, entrevistas e anotações de campo. Em seguida, essa lista foi reorganizada identificando as disputas às quais essas conexões estavam vinculadas - assim, foram sistematizadas as controvérsias. Posteriormente, no interior das controvérsias, as associações foram organizadas cronologicamente. Esse método é uma adaptação da cartografia das controvérsias (Latour, 2008; Venturini, 2010). Desloca o foco da descrição das controvérsias em si para o entendimento das questões que levam atores a buscar conexões transnacionais.

Os dados provêm de fontes documentais da Contag (anais de todos os seus congressos nacionais, relatórios anuais e publicações como jornais e declarações) e do MPA (pautas nacionais, documentos públicos mantidos por militantes do movimento e publicações reunidas durante visitas de campo). Foram consultados arquivos da CPT e do MST, assim como o Arquivo Lyndolpho Silva da Universidade Federal Rural do Rio de Janeiro (UFRRJ). As informações, que abrangem o período desde a fundação das organizações até o ano de 2017, foram complementadas por entrevistas e observações participantes. Entre 2015 e 2017 foram realizadas 15 entrevistas com militantes do MPA e outras 28 com ativistas ligados à Contag (14 sindicalistas, seis assessores e oito ativistas ou funcionários de organizações internacionais com as quais a Contag se relaciona). Estive no $1^{\circ}$ Congresso Nacional do MPA (2015), visitei cooperativas no oeste de Santa Catarina, acompanhei o $12^{\circ}$ Congresso da Contag (2017), participei de um curso sobre cooperação internacional, e compareci a diversos encontros da Reunião Especializada da Agricultura Familiar (Reaf) no Brasil, Uruguai e Paraguai, entre 2009 e 2011.

O artigo está estruturado em cinco tópicos. Nos dois primeiros são analisados os processos de transnacionalização da Contag e do MPA partindo das controvérsias em que se engajaram. No terceiro tópico argumento sobre a utilidade das controvérsias como ferramenta analítica. No quarto ponto proponho uma modificação na definição de transnacionalização a partir dos casos analisados e, por fim, teço conclusões em diálogo com a literatura sobre movimentos rurais transnacionais, destacando condições para a consolidação da inserção transnacional dos movimentos estudados. 


\section{AS CONTROVÉRSIAS TRANSNACIONAIS DA CONTAG}

As controvérsias transnacionais nas quais a Contag se envolveu, ou que ajudou a criar, foram organizadas em seis categorias: controvérsias sindicais, condições de trabalho, liberalização do comércio internacional, modelo de agricultura e presença das mulheres. A sexta controvérsia, presença de jovens nos debates transnacionais, é mencionada, mas não configura tema permanente.

Antes mesmo da fundação da Contag, já havia conexões discursivas entre questões internacionais e as demandas dos então denominados lavradores e trabalhadores agrícolas. Elas estão registradas nos documentos dos trabalhadores que se organizavam no início da década de 1960 e criticavam o "capital colonizador estrangeiro" vinculando-o ao monopólio da terra; isto é, ao latifúndio ao qual se opunham (I Congresso, 1961).

Criada a Contag, em 1963, a construção de associações (laços/conexões) com grupos provenientes de outros países ocorreu em torno de disputas sobre o modelo de sociedade defendido pela confederação sindical. Essas disputas traduziam-se em articulações com as diferentes correntes do sindicalismo internacional e em debates sobre as condições de atuação do sindicalismo sob o governo autoritário instalado em 1964. Parte dessas interações provinha de militantes de partidos de esquerda que há muito tempo mantinham relações com aliados internacionais - alguns deles, inclusive, valeram-se dessas conexões para encontrar exílio durante o período de ditadura.

Essas conexões estão registradas nas memórias de sindicalistas que viajaram a eventos internacionais ou que negociaram apoios financeiros - muitas vezes para a construção de edifícios e sedes das federações estaduais. Em anais de congressos também é visível uma intensa troca de correspondências, indicadoras de que a Contag interagiu com as três vertentes do sindicalismo internacional: do bloco soviético, de países capitalistas e com democratas cristãos, equilibrando-se assim no complexo jogo de forças sindicais (Contag, 1973, 1979, 1985; Ricard, 2010). O sindicalismo internacional do período foi marcado pela centralidade de organizações vinculadas aos debates político-partidários e às disputas por modelos de sociedade e economia. Foi reconfigurado, 
nas décadas seguintes, em decorrência do fim do bloco socialista, da ascensão do capitalismo financeiro, e também pelas formas de ação renovadas pelas novas solidariedades globais (Waterman, 2001).

Nessa primeira controvérsia estão situados os debates sobre liberdade sindical, nos quais, para fundamentar seus argumentos, a Contag recorreu a normas da Organização Internacional do Trabalho (OIT) - notadamente, à sua convenção de número 87 (Contag, 1979:10-11). Essas controvérsias, que denomino sindicais, foram estabelecidas praticamente desde a fundação da Contag e existem até os dias atuais, sendo fontes importantes para a inserção transnacional da confederação brasileira. Entretanto, ao longo do tempo elas foram transformadas pelas mudanças na configuração do sindicalismo internacional após a queda da União Soviética; pelas transformações políticas e econômicas no Brasil; e por mudanças no interior da Contag.

Na década de 1990, frente aos novos desafios colocados pela liberalização da economia e pelo aprofundamento da globalização, sindicalistas da Contag decidiram reforçar e reorganizar suas articulações internacionais. Buscavam obter informações qualificadas e estabelecer relações orgânicas (Contag, 1995:104). Para isso, recorreram às articulações sindicais facilitadas pelo contexto de aproximação com a CUT, que mantinha fortes laços internacionais (Costa, 2005). Internamente, a Contag criou uma estrutura voltada para as relações internacionais vinculada à sua vice-presidência. Após decisão de seu 7ํㅡ Congresso, em 1998, filiou-se à União Internacional de Trabalhadores da Alimentação, Agricultura, Hotelaria, Restaurantes, Tabaco e afins, a UITA (Contag, 1998). Contatos com organizações sindicais também foram usados na busca de aliados no Mercosul.

A UITA passou a ser convidada a apoiar negociações salariais que envolviam empresas multinacionais no Brasil, atuando durante as negociações locais ou exercendo pressão nas sedes internacionais das empresas. Paralelamente, precisou aprender a lidar com uma afiliada diferente, que representava não apenas trabalhadores assalariados mas também agricultores não assalariados. Essa foi, até 2015, uma das singularidades do sindicalismo rural, que por determinação do Ministério do Trabalho representava todos os trabalhadores do campo, proprietários ou arrendatários na agricultura familiar, fossem assalariados permanentes ou temporários (Medeiros, 2014:250). Tais características impeliram a regional latino-americana da UITA a criar estratégias 
para atuar com trabalhadores não assalariados. Uma delas foi uma campanha internacional contra a violência sofrida por trabalhadores rurais - empregando um modelo de ação comum entre ativistas transnacionais (Keck e Sikkink, 1998). Esse é um bom exemplo de como novas conexões, estabelecidas para resolver dilemas transnacionais, são capazes de provocar mudanças nos atores associados.

Por sua vez, a Contag passou a participar de atividades internacionais a convite da UITA, que valoriza sua liderança regional e seu enorme quadro de filiados. Também recebeu - e ainda recebe - visitas de delegações sindicais internacionais interessadas em suas práticas e formas de interagir com o governo brasileiro ${ }^{2}$. Porém, ainda que tenha estabelecido conexões e se engajado em controvérsias internacionais sobre direitos trabalhistas, a Contag nunca chegou a ser um ator poderoso nesse ambiente se comparada, por exemplo, aos grandes sindicatos europeus, que têm acesso a mais recursos financeiros e trajetória consolidada de atuação internacional. Conexões sindicais, em resumo, não estão restritas às primeiras décadas da Contag, tendo se desdobrado em novas associações e atividades ao longo do tempo. Elas também estão presentes em outras disputas, como veremos adiante.

Um segundo conjunto de controvérsias é relativo a condições de trabalho. Nele, além dos aliados sindicais, a Contag se aproximou da Organização Internacional do Trabalho (OIT), com a qual desenvolve desde a década de 1990 ações de combate ao trabalho infantil e ao trabalho escravo. Incluiu esses temas em sua agenda e desenvolveu experiências como oficinas para formação de trabalhadores, produção de materiais impressos, programas de rádio e páginas na internet. Com isso, levou debates a agricultores e agricultoras nos municípios por meio da sua estrutura de federações e sindicatos. Traduziu para atores locais os parâmetros de condições de trabalho acordados internacionalmente e, por vezes, precisou traduzir questionamentos oriundos das práticas locais para a organização internacional.

O papel da tradução nas interações transnacionais vem sendo ressaltado pelas teóricas feministas interessadas na circulação de discursos e práticas. Entendem que, ao substituir uma ideia por outra semelhante, são inevitáveis os deslocamentos que impossibilitam traduções literais (Costa, 2014). No mesmo sentido, sindicalistas brasileiros não apenas incorporaram categorias e debates internacionais, mas também 
as adequaram à linguagem e aos debates do sindicalismo rural, em processos nos quais as ideias internacionais foram transformadas ou questionadas pelos ativistas locais (OIT, 1997, 2015).

A partir da década de 1980 uma nova controvérsia relativa à liberalização do comércio internacional começou a tomar forma. A Contag e seus aliados questionavam o impacto dos processos de liberalização comercial sobre trabalhadores rurais e agricultores. $\mathrm{O}$ debate se prolongou pelos anos seguintes e, no final da década de 1990, apoiada por organizações não governamentais, a confederação enviou lideranças para os protestos de Seattle, Cancún e Gênova. Relatos dessas participações enfatizam a dupla estratégia de garantir presença nas manifestações do lado de fora das reuniões, ao mesmo tempo que tentavam incidir nas posições do governo brasileiro nos debates oficiais, demandando que assegurassem salvaguardas para os pequenos agricultores. Essa estratégia reflete uma leitura de que é necessário pressionar governos para que os resultados das negociações sejam menos danosos para os trabalhadores. Paralelamente, a Contag foi parte da campanha brasileira contra a Área de Livre Comércio das Américas (ALCA), que reuniu 10 milhões de votos em seu plebiscito popular ${ }^{3}$ (Berrón, 2007; Silva, 2008). Essas ações contribuíram para o congelamento das negociações sobre a ALCA em 2003, resultado da intervenção do recém-eleito presidente Luiz Inácio Lula da Silva - apoiado pelas organizações da campanha que comemoraram a mudança de curso das negociações internacionais. As controvérsias sobre comércio tiveram enorme destaque no final dos anos 1990 e início da década de 2000, tendo perdido força durante os governos petistas (2003-2016). Esses debates, porém, mantiveram-se latentes e ganharam novo fôlego após 2016, com as mudanças na orientação da política externa no governo Temer.

Foi no bojo dos debates sobre comércio que a Contag levou a categoria de agricultura familiar para suas articulações internacionais. Apresentando-a como forma de organizar a produção agrícola e a vida no campo com base no trabalho familiar, argumentava que esse modelo precisava ser considerado nos debates internacionais, uma vez que é afetado de formas específicas pelos acordos internacionais firmados pelo Brasil. No início do governo Lula, as disputas sobre os acordos e regras comerciais internacionais passavam, além da ALCA, pelo Mercosul e pela Organização Mundial do Comércio (OMC). Na perspectiva da Contag, a questão girava em torno de diminuir os impactos sobre trabalhadores assalariados e agricultores familiares. Foram anos 
de tentativas para que esta questão fosse considerada nos debates agrícolas no Mercosul. A opção pela atuação no âmbito do Mercosul foi um dos temas de tensão entre a Contag e a Coordenadoria Latino-Americana de Organizações do Campo (Cloc) - que depois se tornou o braço regional da Via Campesina - e marcou o afastamento entre os dois grupos. Essa cisão levou a Contag a reforçar articulações com organizações sindicais de outros países do bloco, buscando fortalecer suas demandas.

A partir de 2003, as redes, organizações e movimentos sociais que questionavam a liberalização do comércio internacional estabeleceram canais de interlocução com setores do governo Federal - em especial com o Ministério do Desenvolvimento Agrário (MDA) e o Ministério das Relações Exteriores (MRE). Uma série de eventos e reuniões aproximou ou reaproximou esses atores. Alguns dos novos integrantes do governo já tinham atuado ou mantinham conexões com atores não estatais, estabelecendo o que Abers, Serafim e Tatagiba (2014) denominaram experimentações criativas com padrões históricos de interação Estado-sociedade. Setores menos poderosos no interior do governo valeram-se da capacidade de pressão da sociedade civil para alavancar suas propostas, enquanto organizações da sociedade civil cavaram espaços institucionais com apoio de seus aliados no governo. Nesse processo, a Contag encontrou um caminho próprio para sua atuação transnacional de maneira permanente, sustentada e com maior impacto externo e interno à Confederação. A presença de um governo com o qual compartilhava algumas propostas foi central nesse processo, mas não explica tudo. A mudança de patamar da atuação transnacional da Contag, nesse período, é mais bem entendida a partir da construção de uma plataforma política que a confederação brasileira carregou (e fortaleceu) nos debates transnacionais dos quais participou.

Em fóruns internacionais, a Contag e seus aliados passaram a afirmar a agricultura familiar como maneira de organizar práticas agrícolas presente em todos os países do Mercosul. Associaram a isso demandas por políticas de crédito, acesso à terra, comercialização, assistência técnica e pela participação de sindicalistas nos espaços institucionais regionais (Carvalho, 2011). A essas disputas pela existência da agricultura familiar nos debates internacionais, denomino controvérsia sobre o modelo de agricultura. 
Nesse processo, a Contag estabeleceu novas alianças e construiu relações estáveis com atores sindicais de outros países. Foi também ator central para a criação de uma organização regional de agricultores familiares a partir da qual as lideranças sindicais puderam passar a falar regionalmente - a Confederação de Organizações de Produtores Familiares do Mercosul (Coprofam). Reunindo organizações sindicais e associações nacionais, a Coprofam conseguiu levar suas demandas às instâncias de coordenação do Mercosul; e quando obteve apoio dos governos nacionais, contribuiu para a criação de uma Reunião Especializada sobre Agricultura Familiar (Reaf), estabelecida para subsidiar decisões regionais sobre o tema (von Bülow e Carvalho, 2012; Nierdele, 2016). Isso ocorreu depois que organizações sindicais da região passaram quase uma década tentando emplacar suas pautas nos debates sobre trabalho no Mercosul, sem sucesso. Uma das principais inovações da Reaf foi a presença formal de atores não estatais nas reuniões semestrais - pouco usual em espaços oficiais de organizações internacionais. Esse formato ajudou a conferir um traço de forte participação institucional na ação transnacional da Contag.

Nessa controvérsia, pela primeira vez, a Contag não apenas se engajou em debates transnacionais, mas foi um dos grupos essenciais para que as discussões sobre agricultura familiar ganhassem corpo. Ela contribuiu para que novos elementos fossem associados ao bloco e, portanto, para que ele fosse modificado. Assim, um tema antes ausente passou a existir no âmbito regional. Além disso, estabeleceu-se uma disputa sobre o significado da agricultura no bloco. Internamente à Confederação, ter ajudado a estabelecer essa controvérsia alterou o panorama da sua inserção transnacional. A associação com a agricultura familiar passou a levá-la para outros lugares, mas também carregou grupos no interior da Contag para uma ação transnacional sustentada - notadamente, as mulheres e em menor medida a juventude. Isso foi possível porque, na medida em que articularam a existência da agricultura familiar, a demanda por políticas públicas e a proposta de que tais políticas precisavam ser construídas com a participação dos agricultores e agricultoras familiares, a Contag e seus aliados produziram efeitos no ambiente transnacional. Tendo considerado positivos os impactos gerados por essas ideias associadas, elas passaram a ser utilizadas repetidas vezes e reforçadas. 
Na estruturação da Reaf, a Coprofam e a Contag fortaleceram relações com setores dos governos nacionais encarregados da agropecuária, contribuíram para a difusão dessa agenda em países que até então não utilizavam essa categoria ${ }^{4}$, e fortaleceram laços com a Organização das Nações Unidas para a Agricultura e Alimentação (FAO) e com o Fundo Internacional de Desenvolvimento Agrícola (FIDA). Recursos e ideias circularam por meio dessas conexões, fazendo com que notícias sobre a experiência da Reaf se espalhassem.

Em 2009, a Coprofam foi convidada a fazer parte da campanha que solicitava à ONU a instalação de um Ano Internacional da Agricultura Familiar (AIAF), proposto pelo Fórum Rural Mundial (FRM). A Coprofam abraçou a proposta e tornou-se uma de suas principais defensoras nas Américas. A campanha foi bem-sucedida e o ano internacional ocorreu em 2014, contribuindo para a difusão da ideia da existência de agricultores familiares e de suas maneiras específicas de produzir alimentos - novamente, ao lado de demandas por políticas públicas e por participação institucional em países da África, Ásia e Oceania. Juntas, agricultura familiar, participação institucional e políticas públicas continuaram viajando e chegaram, agora pela via da sociedade civil, à FAO e a novos países.

Quando o Mecanismo da Sociedade Civil (MSC) foi criado pela FAO, no contexto de reforma do seu Conselho de Segurança Alimentar, agricultores familiares também se fizeram presentes (McKeon, 2015). A Coprofam obteve um assento representando produtores de pequena escala e coube à Contag representá-la nos períodos de 2010-2012, 20152017 e 2018-2020.

Debates sobre a existência da agricultura familiar também chegaram, por outros caminhos, à Comunidade dos Países de Língua Portuguesa (CPLP), que criou o Mecanismo de Facilitação da Participação da Sociedade Civil em seu Conselho de Segurança Alimentar e Nutricional. Dirigentes e assessores da Contag participam ativamente desses espaços. Nesse processo, a Coprofam e a Contag não apenas foram transformadas, mas contribuíram - ao lado de outros atores - para que a agricultura familiar fizesse parte das disputas sobre a agricultura no Cone Sul das Américas e, depois, em outras regiões. 
Por fim, as conexões estabelecidas nesse conjunto de articulações internacionais tiveram impactos no interior da confederação. $\mathrm{Na}$ medida que o debate sobre gênero foi inserido na Reaf, passaram a discutir a presença de mulheres nas interações transnacionais, a violência contra mulheres e a existência de políticas voltadas a esse público. Nesse processo, as mulheres sindicalistas obtiveram novos espaços para levar suas pautas, ampliaram articulações preexistentes e conquistaram novas aliadas - entre elas, as mulheres do Fórum Rural Mundial.

Mulheres rurais já tinham estabelecido conexões com outros coletivos transnacionais desde o ciclo de conferências sobre Mulheres na ONU, nas décadas de 1970 e 1980. Tinham participado também da construção de articulações regionais (Thayer, 2010). Porém, a Reaf lhes proporcionou frequentes espaços de encontro e um ambiente favorável para que suas demandas fossem levadas em conta na formulação de políticas públicas em países do bloco. Em 2015, teve início uma articulação para construir o que vem sendo chamado de "Margaridas pelo Mundo", associando à Marcha das Margaridas os intercâmbios entre mulheres rurais de diversos países. A Marcha é um evento massivo que ocorre desde 2000, reunindo mulheres rurais em Brasília, para defender uma agenda própria (Silva, 2008). De forma semelhante, as articulações no Mercosul propiciaram a presença contínua da juventude em atividades transnacionais.

Os Quadros 1 e 2 sintetizam as controvérsias identificadas pela pesquisa. As controvérsias elencadas resultam de uma sistematização das associações identificadas na pesquisa em torno de disputas centrais. As cores diferenciam cada uma das disputas. 
Quadro 1

Síntese das controvérsias transnacionais da Contag (1960-2017)

a) Controvérsias sindicais

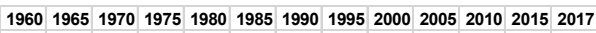

Modelo de ação sindical/ filiação a organização internacional

Resistência à ditadura e apoio a exilados

Liberdade sindical

b) Contovérsias sobre condições de trabalho

Trabalho escravo

Trabalho infantil

c) Controvérsias sobre a liberalização do comércio internacional

Impacto do comércio internacional

Acordos de livre comércio - luta contra ALCA

Acordos de livre comércio - agricultura na OMC

d) Controvérsias sobre modelo de agricultura

Agricultura familiar (AF) no Mercosul

Demanda pelo Ano Internacional da Agricultura Familiar

Demandas por politicas públicas para AF em outros espaços

e) Controvérsia sobre a presença das mulheres

Mulheres na integração regional

Margaridas pelo mundo

Fonte: Elaboração própria.

O quadro mostra que muitas das controvérsias aqui narradas ocorreram simultaneamente. As primeiras, sindicais, têm início ainda nos anos 1960 e, desdobrando-se em diferentes disputas, continuam existindo atualmente. A controvérsia sobre comércio internacional teve início na década de 1980, ganhou força nos anos 1990 e segue em curso - ainda que com menor destaque. Já a controvérsia sobre o modelo de agricultura, com ênfase na agricultura familiar, teve início na década de 1990 e gerou inúmeros desdobramentos na década seguinte, também permanecendo em curso até os dias correntes. A visualização das simultaneidades é relevante por indicar que os temas não foram abandonados, mas transformados e reconfigurados ao longo do tempo. Cabe destacar a continuidade das articulações sindicais e sua centralidade para a Contag e, também, a multiplicação recente de alianças com atores de outros perfis - uma das marcas do sindicalismo internacional contemporâneo (Waterman, 2001).

\section{AS CONTROVÉRSIAS TRANSNACIONAIS DO MOVIMENTO DOS PEQUENOS AGRICULTORES}

Na experiência do MPA, referências a questões internacionais estiveram presentes desde as primeiras pautas nacionais (1998, 2001 e 2002). Incluíram demandas pelo controle da importação de alimentos e por subsídios e compensações, como medidas de proteção à agricultura nacional (Costa, 2014). Porém, não foi pela via das controvérsias sobre comércio internacional que o MPA construiu suas associações transna- 
cionais. Essas controvérsias perderam relevância pouco depois, como se percebe no Quadro 2. Os debates priorizados e que produziram articulações duradouras foram aqueles relativos à soberania alimentar, presentes desde 2001 nas pautas nacionais da organização.

Quadro 2

As controvérsias transnacionais do MPA (1990-2017)

\begin{tabular}{|c|c|c|c|c|c|c|}
\hline & 1998 & 2000 & 2005 & 2010 & 2015 & 2017 \\
\hline \multicolumn{7}{|c|}{ a) Controvérsias sobre a liberalização do comércio internacional } \\
\hline \multicolumn{7}{|c|}{ b) Controvérsias sobre soberania alimentar } \\
\hline & & & & & & \\
\hline \multicolumn{7}{|c|}{ c) Controvérsias sobre modelo de agricultura } \\
\hline \multicolumn{7}{|l|}{ Agricultura camponesa } \\
\hline \multicolumn{7}{|l|}{ Sementes e biodiversidade } \\
\hline \multicolumn{7}{|l|}{ Sementes crioulas } \\
\hline \multicolumn{7}{|c|}{ Direitos camponeses na CDB } \\
\hline \multicolumn{7}{|c|}{ Direitos camponeses no TIRFAA } \\
\hline \multicolumn{7}{|l|}{ Agrotóxicos } \\
\hline \multicolumn{7}{|c|}{ d) Controvérsias sobre a presença das mulheres } \\
\hline \multicolumn{7}{|l|}{ Violência contra mulheres } \\
\hline \multicolumn{7}{|l|}{ Feminismo camponês } \\
\hline Sementes e biodiversidade & & & & & & \\
\hline
\end{tabular}

O conceito de soberania alimentar sugere que se considere essencial ao combate à fome não apenas a disponibilidade de alimentos, mas também o direito de cada país produzir alimentos para sua população e definir suas políticas agrícolas e alimentares. Esse conceito foi difundido internacionalmente pela Via Campesina em meio aos debates sobre acesso a alimentos e combate à fome travados na FAO em 1996. A soberania alimentar passa, na formulação da Via Campesina, pela possibilidade de agricultores de pequeno e médio porte terem domínio sobre os insumos e processos de produção e distribuição de alimentos e serem capazes de tomar decisões sobre eles (Desmarais, 2007).

O MPA aproximou-se da Via Campesina a partir de 2001, durante os Fóruns Sociais Mundiais, participando das conferências, acampamentos e de ações diretas - como a ocupação de campos de experimentos de sementes de empresas transnacionais. Pouco depois, filiou-se à rede transnacional de camponeses.

Em 2003 o MPA reformulou seu projeto político, denominado Plano Camponês, e incorporou a soberania alimentar como um de seus eixos. Desde então, vem traduzindo-o para seus militantes e incorporando outras soberanias em sua plataforma política - energética, genética, hídrica, territorial. No Plano Camponês, define soberania alimentar 
em três itens "Comida (...) local, vinculada à cultura, modo de vida; produzir de tudo um pouco; sem veneno, buscando equilíbrio ambiental" (Silva, 2009:4). O MPA somou-se aos debates e às ações da Via Campesina em defesa da soberania alimentar; mas, para além disso, passou a empregar esse conceito em suas próprias formulações e a orientar suas práticas por ele. No Rio Grande do Sul, com a proposta de garantir a soberania alimentar e energética de comunidades rurais sem pressionar ecossistemas locais, implementou um centro de formação, pesquisa e produção de alimentos e energia (Silva, 2016). No Nordeste, iniciativas nesse sentido vêm ganhando a forma de casas de sementes e feiras locais.

No tema da agricultura, as condições e maneiras de produzir alimentos são centrais para o MPA, que desde 2003 se identifica como um movimento de camponeses. Isso informa as formulações do movimento sobre o modelo de agricultura camponesa que defende, marcado pela oposição ao capitalismo. Denomino as articulações transnacionais construídas em torno desse tema como controvérsias sobre o modelo de agricultura, nas quais o MPA se insere diferenciando a "agricultura camponesa" tanto da agricultura familiar quanto da agricultura capitalista baseada no agronegócio. Em 2010, o movimento brasileiro apresentou sua formulação sobre as particularidades da agricultura camponesa no congresso da Cloc, braço regional da Via Campesina. O evento marcou uma inflexão na estratégia do MPA para sua inserção na Cloc e na Via Campesina: até então pontual e descontínua, passou a ser mais constante e planejada, resultando no aumento da sua visibilidade internacional de suas formulações (MPA, 2010:21). Essa experiência indica que a filiação a uma organização internacional não foi, por si só, caminho garantido para a relevância nos debates ali travados. Ao contrário disso, ela só se consolidou quando o MPA organizou formulações próprias para os debates, primeiro internamente e, depois, as apresentou (e disputou) externamente.

No Brasil da década de 1990, o MPA discutia o modelo tecnológico adotado pelos agricultores para a produção de alimentos no bojo das lutas por crédito; do crescimento do número de pequenos agricultores integrados às cadeias produtivas agrícolas; e da preocupação com o contínuo endividamento das famílias via a aquisição de insumos para a produção. Buscando alternativas que entendia serem mais adequadas ao perfil dos camponeses, o MPA se envolveu em debates sobre o modelo de agricultura especialmente por meio de disputas sobre 
sementes e agrotóxicos. Essas três disputas - sobre a existência de uma agricultura camponesa, sobre sementes e biodiversidade e sobre o uso de agrotóxicos - conformam a controvérsia sobre o modelo de agricultura na experiência do MPA.

No caso das sementes, o MPA desenvolveu experiências de recuperação, armazenamento e compartilhamento de variedades crioulas, ao lado de agricultores e sindicatos municipais, sobretudo em Santa Catarina (Campos, 2007; Niemeyer, 2014). Em âmbito nacional, engajou-se nas disputas sobre a adoção de organismos geneticamente modificados e participou ativamente da campanha Brasil Livre de Transgênicos. Em 2001, a disputa sobre a produção de sementes transgênicas no Brasil foi o mote para que o MPA se unisse à Via Campesina na ocupação da área de experimentos da multinacional Monsanto, no dia da abertura do 1ํo Fórum Social Mundial (MST, 2001). Naquele período, o uso de tais sementes ainda não havia sido liberado, mas já existiam denúncias de que boa parte da soja produzida no Rio Grande do Sul era geneticamente modificada.

Pouco depois, em 2004, o MPA e a Via Campesina transformaram a Festa das Sementes Crioulas de Anchieta (SC) em um evento internacional. Tratava-se de um misto de feira agropecuária e espaço de formação que vinha sendo realizada por seus militantes e parceiros locais. Ali era divulgada a prática de recuperar, multiplicar, manter e compartilhar sementes crioulas. A participação da Via Campesina projetou a atividade internacionalmente e contribuiu para o fortalecimento do lugar do MPA no debate sobre sementes. As práticas em Santa Catarina ganharam projeção como contraponto às sementes transgênicas, reforçando o discurso sobre a viabilidade de produção menos dependente da agricultura de mercado, com impactos positivos sobre autonomia, saúde (pelo menor uso de agrotóxicos) e sobre as finanças das famílias. A festa possibilitou também visibilidade regional à campanha Sementes Patrimônio do Povo a Serviço da Humanidade, lançada pela Via Campesina no Fórum Social Mundial de 2003 (Niemeyer, 2014).

A festa passou a receber visitas de delegações internacionais, que puderam conhecer práticas e estratégias locais. Os intercâmbios ali realizados foram apresentados como iniciativas de solidariedade entre os povos, componente importante das interações transnacionais da Via Campesina. A festa tornou-se espaço de trocas políticas e afetivas, con- 
tribuindo para que os efeitos da ação fossem também o delineamento de "geografias afetivas de conexão"; isto é, a "formas de identificação 'mais do que racionais', trocas e articulações produzidas por meio de práticas políticas espaciais" (Featherstone, 2008:45). Solidariedades, nesse sentido, têm efeitos na produção das redes e dos atores que as compõem, em uma perspectiva que supera o acento estritamente político (e técnico) das abordagens focadas nas controvérsias.

Como estratégia para se contrapor ao domínio daquela que denomina "agricultura capitalista", o MPA passou a desenvolver iniciativas de criação de estruturas de apoio à produção vinculadas aos territórios nos quais atuava. Em Santa Catarina essa estratégia tomou a forma de disputa sobre sementes. Ali, criou-se um centro de armazenamento, classificação e beneficiamento de sementes cuja formulação conectou debates sobre capitalismo, soberania alimentar e metodologias de reprodução de variedades crioulas. Essas experiências foram levadas pelo MPA ao Congresso da Cloc, em 2010, do qual o MPA saiu com uma agenda de intercâmbios sobre sua experiência com sementes. O primeiro intercâmbio foi realizado no Paraguai (MPA, 2010). Em 2011, estabeleceu cooperação com a Venezuela, enviando 218 toneladas de feijão e alguns militantes para acompanhar a produção. E em 2012, camponeses brasileiros foram a Moçambique, apoiados por organizações não governamentais, para trabalhar com recuperação de sementes. Essas conexões desdobraram-se na inserção em outras disputas e experiências, como a construção de uma escola de agroecologia na Venezuela e a participação numa coalizão internacional que questiona o projeto nipo-brasileiro Pró-Savana em Moçambique (MPA, 2015). Vê-se aqui, novamente, as conexões entre antagonismos e solidariedades e como contribuem para conformar tanto os atores como o perfil de suas interações.

Engajado nas disputas sobre o acesso dos agricultores às sementes $\mathrm{e}$ ao conhecimento a elas associado, o MPA vinha participando também do GT de Biodiversidade da Articulação Nacional de Agroecologia (ANA). Em 2006, quando o Brasil sediou a $8^{\text {a }}$ Conferência das Partes da Convenção da Diversidade Biológica, a COP-8, um militante do MPA fez parte do grupo de ativistas da delegação oficial brasileira. $\mathrm{O}$ movimento também participou da organização de atividades paralelas à $\mathrm{COP}$ em Curitiba. A partir de então, integrantes do MPA passaram a acompanhar o Coletivo de Biodiversidade da Via Campesina Internacional. E, depois de 2011, o MPA passou a compor as delegações que 
participaram das Convenções das Partes, a cada dois anos, tornando-se uma das organizações que conseguiu acumular maior experiência no debate sobre biodiversidade. Em 2015, o MPA foi a voz dos camponeses na reunião da Comissão de Recursos Genéticos para Alimentação e Agricultura da FAO, defendendo a valorização do papel dos agricultores na conservação de sementes e dos recursos genéticos. Outras intervenções e apresentações de experiências foram realizadas nos anos seguintes, indicando a consolidação do MPA como ator relevante nesse campo e mantendo as conexões com a Via Campesina ${ }^{5}$.

Na controvérsia sobre o uso de agrotóxicos, por volta de 2010, o MPA era, nacionalmente, uma das organizações que vinha atuando na crítica ao uso de pesticidas na agricultura. Questionava os tipos de veneno permitidos, o volume empregado, e seus impactos na saúde dos produtores e produtoras rurais e da população em geral. Em 2003, as mulheres do movimento propuseram uma Campanha Nacional Contra os Agrotóxicos, que acabou sendo assumida por outros grupos e tornou-se uma campanha nacional. Em 2010, o MPA levou ao V Congresso da Cloc a proposta de uma Campanha Continental contra os Agrotóxicos, o que foi aceito. A iniciativa, mais tarde, foi adotada pela Via Campesina e transformada em campanha internacional. O envolvimento na luta contra os agrotóxicos e sua capacidade de formular propostas colocou o MPA em uma posição de destaque nas articulações regionais. Vê-se, aqui, o movimento de camponeses brasileiros sendo capaz de levar novas associações à organização internacional à qual é vinculado - contribuindo, portanto, para a composição do que entendemos como transnacional.

Por fim, a última das principais controvérsias a partir das quais o MPA estabeleceu conexões internacionais é relativa aos direitos das mulheres (ver item $d$, Quadro 2). Ativistas mulheres fazem parte do movimento desde a sua criação e muitas delas já atuavam em sindicatos e comunidades, além de manterem conexões com movimentos de mulheres ou feministas. A partir da organização do Plano Camponês, em 2003, foram intensificados os debates sobre gênero e sobre a organização das mulheres no movimento (Tavares, Costa e Fagundes, 2016:17). Os debates passam por questões como a ausência das mulheres nos espaços de decisão e a invisibilidade de seu trabalho na agricultura e nos arranjos familiares, o que não raro resulta em submissão econômica e abre espaço para diversas formas de violência. 
Em que pese a maior presença de homens do que de mulheres nas articulações internacionais do MPA, por meio de debates e campanhas da Via Campesina, elas vêm conquistando espaços e construindo alianças dentro e fora do movimento. Com a associação à Via Campesina as mulheres tiveram acesso a novas ferramentas para se contrapor à desigualdade de gênero. A Campanha Mundial "Basta de violência contra as mulheres", lançada pela Via Campesina Internacional em 2008 e pela Via Campesina Brasil em 2010, foi adotada e vem sendo usada em debates voltados para o interior do movimento. Esses debates questionam práticas militantes permeadas por relações desiguais, sendo mote para a promoção de discussões com mulheres e homens dos grupos de base do MPA e com a sociedade em geral. Nessa controvérsia emerge um emprego peculiar das campanhas transnacionais, diferente do padrão bumerangue identificado por Keck e Sikkink (1998). No padrão bumerangue, o foco reside em obter acesso aos Estados nacionais por meio de aliados internacionais. Já as campanhas da Via Campesina, além da preocupação com atores institucionais, visam também o trabalho voltado para o interior dos movimentos, facilitando a entrada de alguns debates e promovendo transformações de atitudes dos próprios ativistas.

No caso da campanha contra a violência, a Via Campesina tem papel de intermediação de pautas feministas e de gênero - como, aliás, também fazem outras organizações nacionais e transnacionais. O processo é similar ao que Alvarez (2014) denominou sidestreaming; porém, a difusão das ideias feministas ocorre no interior do movimento nacional. As militantes traduzem conceitos e pressionam pela visibilidade do tema no movimento. Atualmente, as mulheres do MPA estão engajadas nos debates sobre o que seria a construção de um feminismo camponês.

Na experiência do MPA, a transnacionalização é perpassada desde os anos 2000 por sua associação à Via Campesina. A filiação foi facilitada pelo fato de o MPA ser politicamente próximo ao MST - relevante nessa rede internacional de camponeses desde a sua fundação. Porém, se a filiação reforça a importância de estar vinculado a um coletivo internacional para se inserir em debates além das fronteiras de forma sustentada, ela também indica que a filiação não resultou automaticamente na multiplicação de laços transnacionais. Inicialmente, o que houve foi um extenso trabalho de tradução do conceito de soberania alimentar para as pautas do MPA e, em certa medida, a adoção da 
identificação como camponeses parcialmente relacionada à circulação desse conceito na Via Campesina - também conectada aos debates de atores rurais brasileiros sobre o tema (Carvalho, 2005).

Aos poucos, o MPA foi participando com mais solidez de disputas internacionais relativas a temas que lhe eram caros nacionalmente. $\mathrm{E}$ a partir delas estabeleceu novas conexões transnacionais, com destaque para questões da biodiversidade, das sementes e dos agrotóxicos. Além disso, seus militantes passaram a se comunicar melhor em outros idiomas, em especial o espanhol, podendo assim superar a barreira linguística (Alvarez et al., 2014).

Nesse processo, foi relevante o fato de o MPA ter formulado sua leitura peculiar sobre as disputas em torno do modelo de agricultura e de ter intencionalmente buscado espaços para se colocar nesses debates com suas formulações. A partir dali, quando aportou novos elementos aos debates da Via Campesina, sua atuação se tornou mais estável e gerou novas associações. Isso aconteceu com maior força depois que o MPA reuniu uma maneira específica de lidar com a questão das sementes - uma metodologia própria de conservação e compartilhamento das sementes crioulas - que dialoga com suas premissas sobre o que é a agricultura camponesa, quais maneiras de produção de alimentos a definem, e como ela contribui para a soberania alimentar. Esses elementos, articulados, foram carregados pelo MPA e o carregaram para novas articulações, resultando em diversas conexões diretas com outros grupos e intercâmbios - notadamente sobre suas experiências de produção de alimentos e reprodução de sementes crioulas.

Da visualização das controvérsias transnacionais do MPA sob uma perspectiva cronológica, apresentada no Quadro 2, depreende-se que algumas disputas foram mencionadas mas não tiveram continuidade, não chegando a se consolidar como parte relevante da ação transnacional desse grupo - é o caso da controvérsia sobre comércio internacional. Nem todas as formulações que relacionam questões nacionais e internacionais se transformam em laços duradouros ou em ações específicas.

Outras controvérsias nas quais o MPA se engajou desdobraram-se paralelamente. Indicam, assim como havia ocorrido no caso da Contag, que diversas disputas ocorrem simultaneamente, o que dificulta que sejam narradas em períodos. Esse é um dos ganhos da análise por meio 
das controvérsias: permite ver como diversas disputas desdobraram-se simultaneamente. No item a seguir, retorno a esse tema buscando sintetizar as contribuições analíticas das leituras a partir das controvérsias.

\section{CONTROVÉRSIAS COMO FERRAMENTA ANALÍTICA}

Tendo apresentado uma leitura das transnacionalizações da Contag e do MPA a partir das controvérsias, argumento que elas são categorias analíticas úteis em análises longitudinais da ação coletiva. Controvérsias facilitam a apreensão de simultaneidades e permitem uma leitura que parte dos temas nos quais ativistas e suas organizações buscam interferir para, então, apreender a vasta gama de atividades que empregam em cada disputa.

Periodizações são largamente utilizadas para a compreensão de processos e, em geral, períodos são definidos a partir de suas características predominantes. Na literatura sobre movimentos sociais, debates sobre as contraposições entre novos e antigos grupos e práticas foram travados na segunda metade do século XX; e em que pese a relevância da categoria dos novos movimentos sociais, seus críticos apontaram que características consideradas inovadoras (como multidimensionalidade, demandas não materiais e criação de identidades) já estavam presentes na ação coletiva do século XIX (Alonso, 2009; Calhoun, 1995) . Além do risco apontado por Thompson (1987:23, apud Fernandes, Medeiros e Paulilo, 2009) de ressaltar rupturas e não continuidades, outro problema das periodizações é que elas tendem a se concentrar nas características principais e obliterar a diversidade de práticas e grupos.

Análises de movimentos rurais são atentas a isso. Em uma das mais relevantes sistematizações sobre a formação do MST ${ }^{6}$, Fernandes (2010) organiza-a a partir do que denomina "processo de territorialização" identificando quatro momentos: gestação (1979-1984), consolidação (1985-1989), institucionalização (pós-1990) e um período mais recente de mundialização marcado pela constituição da Via Campesina (pós-1996).

Bringel (2010:206), porém, defende que a "internacionalização do MST é parte de uma política de múltiplas espacialidades do movimento e se inicia inclusive antes de seu nascimento oficial no ano de 1984", por meio de interações entre ativistas exilados das ditaduras do continente e da inserção em campanhas internacionais. Em outro texto (2008), 
Bringel organiza a ação transnacional do MST em quatro planos ou âmbitos de ação. Tem-se um primeiro plano de "articulação duradoura através de espaços e redes transnacionais", como a Via Campesina e a coordenadora regional, a Cloc; um segundo plano de relação com grupos de solidariedade; o terceiro plano de cooperação político-econômica; e, por fim, o plano das articulações com grupos amplos, em campanhas e espaços internacionais (Bringel e Falero, 2008:282). Assim, estudos sobre a transnacionalização do MST dão atenção à dimensão espacial da ação coletiva e já apontam na direção de não trabalhar com períodos, dando ênfase aos modos de articulação.

A não divisão dos processos transnacionais em períodos, aqui proposta, não significa desatenção à temporalidade da ação presente na análise longitudinal, na qual as controvérsias são observadas em seus desdobramentos ao longo do tempo. Porém, a ênfase na simultaneidade das controvérsias contribui para tornar visíveis articulações que não são necessariamente sucessivas. Controvérsias são, portanto, úteis para o entendimento dos múltiplos processos que compõem o esforço de construção de articulações transnacionais e sua transformação.

Ao separar analiticamente as controvérsias, emergem também os diferentes lugares em que as disputas e as solidariedades transnacionais são produzidas. Ativistas rurais colocam em relação lugares diversos, como as roças onde produzem alimentos ou sementes, as salas nas quais se disputam políticas nacionais e suas repercussões nas organizações internacionais. Ao facilitar a descrição de como as mesmas disputas são produzidas em diferentes locais e contribuem para (re) constituí-los, as controvérsias se mostram ferramentas analíticas úteis para compreender as "geografias das solidariedades e antagonismos". Esse conceito dialoga com o entendimento de que os locais do ativismo são, também eles, formados por articulações de elementos heterogêneos (Featherstone, 2008). Esses olhares para lugares e escalas nos afastam da metáfora do local como a base e do global como o topo de uma pirâmide, deslocando a atenção para as conexões que os compõem - mais conexões, mais "global" (Latour, 2008).

Em segundo lugar, controvérsias fornecem ferramentas para analisar movimentos sociais para além de suas ações, que são sua face mais pública. Boa parte das leituras sobre ação transnacional partem de protestos, campanhas ou eventos. Essa é uma questão bastante discutida. Autores como Thompson (1987 [1963]) e Scott (1990) já sugeriram olhar 
para ações coletivas para além de protestos. No Brasil contemporâneo, Abers, Serafim e Tatagiba (2014) sugerem dar atenção não apenas aos repertórios de confronto, mas também aos repertórios de interação.

O deslocamento proposto aqui é um pouco diferente. Trata-se de construir a análise partindo das disputas, das questões que preocupam os movimentos e que fazem com que busquem aliados, construam conexões transnacionais, realizem ações e se engajem em disputas além das fronteiras nacionais. Não importa, a priori, se as ações serão de confronto ou de cooperação - podem, inclusive, ocorrer ambas sob uma mesma controvérsia. Nos debates sobre legislação comercial, a Contag tentou disputar os termos dos acordos buscando influenciar negociadores oficiais, mas também esteve em alguns dos protestos nas ruas de Seattle ou Cancún. Nos debates em torno do trabalho infantil, a relação com a OIT passou pela implementação de projetos e o sindicalismo rural assumiu um papel de tradução dos temas para trabalhadores rurais, tendo também levado questões por eles levantadas nos debates internacionais.

Ao observar as questões nas quais os movimentos se envolvem, torna-se mais fácil enxergar a diversidade de práticas - que incluem os repertórios de ação e de interação, nos termos da teoria da política contenciosa. Assim, nas páginas precedentes, sob as conexões transnacionais, apareceram ações tão diversas como: a construção de sedes locais por meio do acesso a recursos internacionais; a implementação de projetos; a participação institucional; intercâmbios políticos e afetivos entre camponeses; e esforços de formulação de conceitos. Cada uma dessas atividades está relacionada às controvérsias na medida em que compõem os modos encontrados para influenciar questões relevantes para os coletivos estudados. Esses modos de agir, e as associações que engendram, também modificam a composição dos próprios movimentos.

\section{TRANSNACIONALIZAÇÕES: DEFINIÇÕES}

O termo "transnacional" foi empregado por Nye e Keohane (1971:23) como os "contatos, coalizões e interações através das fronteiras estatais que não são controladas por órgãos centralizados de relações internacionais de governos". O conceito foi intensamente empregado e debatido nas décadas posteriores, com ênfase no desafio de articular as interações em diversos níveis (Von Bülow, 2014). 
A transnacionalização de atores não estatais foi objeto de atenção nos anos 1990 e 2000 (Alvarez, 2000; Keck e Sikkink, 1998; Pleyers, 2010; Tarrow, 2005). São mais recentes os estudos a respeito da construção de redes transnacionais por atores rurais (Borras, Edelman e Kay, 2008; Borras Jr. e Edelman, 2016; Desmarais, 2007) e de sua capacidade de proposição e impacto nos debates em organismos internacionais (Edelman, 2012; McKeon, 2015). O internacionalismo sindical, por sua vez, é tema menos proeminente, apesar das recentes transformações e inovações de sua prática transnacional (Evans, 2015).

A partir da análise dos efeitos da organização transnacional sobre as dinâmicas, os discursos e as práticas feministas latino-americanas, Alvarez definiu transnacionalização como

[...] o emprego, por movimentos locais, de enquadramentos discursivos e práticas políticas e organizacionais que são inspiradas, reafirmadas ou reforçadas - ainda que não necessariamente causadas - pelo seu engajamento com outros atores além das fronteiras nacionais por meio de um amplo espectro de contatos transnacionais, discussões, transações e redes, virtuais e "reais" (2000:3).

Essa definição é atenta à circulação de discursos e práticas oriundos da relação com atores de outros locais, não tendo como ponto de partida as atividades (como as campanhas e protestos) realizadas pelos movimentos (Della Porta e Tarrow 2005; Von Bülow, 2014).

Porém, essa definição se foca em como ocorre a transnacionalização, sem incluir elementos que expliquem por que grupos de origem nacional fariam esforços para a construção de laços transnacionais. Os casos aqui analisados sugerem que o fazem quando temas de seu interesse estão em questão - são eles que definem a opção pelo esforço de construir laços além das fronteiras nacionais. Sugiro, então, adicionar à definição o entendimento de que, para haver transnacionalização, é necessário que os grupos busquem estabelecer disputas perpassadas por atores ou temas que têm conexões internacionais - ou, ao menos, engajar-se em disputas existentes, aportando formulações sobre elas. Quando se engajam em debates e polêmicas, transformam em questões públicas os assuntos que, de outra forma, seriam tomados como consensos. Ao fazê-lo, acabam disputando não só os temas em si, mas os elementos que compõem aquilo que compreendemos como transnacional. Essas disputas podem ser tornadas públicas de diferentes maneiras: protestos, 
participação em debates, inserção em campanhas, aporte de recursos e promoção de ações de cooperação e solidariedade internacional, por exemplo. O cerne do argumento é que, sem uma definição interna sobre a relevância de cada tema no interior de cada organização, não faria sentido que empreendessem esforços para se engajar em enquadramentos discursivos ou práticas políticas transnacionais.

Assim, não há transnacionalização se não houver, antes, uma decisão dos grupos de formular argumentos sobre a relevância de engajar-se em discussões internacionais, e de conectar essas questões com suas próprias pautas, objetivos e desafios, em um contínuo trabalho de tradução. Trata-se de entender como elemento definidor do processo de transnacionalização o esforço de incorporar, de formular controvérsias ou de fazer parte delas. A incorporação de enquadramentos discursivos e práticas políticas só é possível quando há, de fato, conexão com disputas que fazem sentido no interior de cada grupo. É por meio do esforço de criar controvérsias, ou de inserir-se nas controvérsias já estabelecidas, que os atores incorporam associações transnacionais em suas atividades. Ao estabelecerem controvérsias ou engajarem-se nas preexistentes, abrem a possibilidade de disputar quais elementos compõem o transnacional, porque é nelas que novas associações são estabelecidas e que as antigas são transformadas.

Sob essa perspectiva, controvérsias são potentes ferramentas analíticas para compreender transnacionalizações porque descortinam um aspecto central desses processos enfocando o que está em seu cerne: as disputas, os temas, as questões sobre as quais os coletivos organizados buscam incidir.

\section{CONSIDERAÇÕES FINAIS: TRANSNACIONALIZAÇÕES, NO PLURAL}

Os relatos aqui apresentados tiveram o objetivo de identificar como a Contag e o MPA construíram suas articulações transnacionais a partir das disputas em que se envolveram. $\mathrm{O}$ termo disputas não subentende que as ações que delas derivam são apenas de confronto; por vezes, tratam-se de atividades de cooperação entre ativistas ou com organizações internacionais. Tais ações produzem tanto solidariedades quanto antagonismos. 
As organizações não apenas se conectaram a controvérsias já estabelecidas, mas participaram de processos que instauraram novas disputas transnacionais. E por meio delas passaram a disputar quais elementos compõem o que se entende por transnacional. O objetivo não foi comparar os percursos da transnacionalização da Contag e do MPA, mas construir narrativas que permitissem apresentar essas trajetórias e seus duplos efeitos: internos, sobre as próprias organizações, suas práticas e os temas que priorizam; e externos, que contribuem para a construção de quais elementos fazem parte "do transnacional."

Essas narrativas situam a atuação de movimentos e sindicatos rurais muito além das reações ao capitalismo global ou como expressões diretas de posicionamentos de classe (Borras Jr., Edelman e Kay, , 2008; Desmarais, 2007; Rubbo, 2013; Stédile, 2007). Afastando-se da tendência de explicar a construção de articulações transnacionais pela globalização, pela existência de organizações intergovernamentais ou pelo esvaziamento dos Estados, Borras Jr. e Edelman (2016:2) consideram "experiências nacionais e regionais, culturas políticas e memórias históricas como elementos constitutivos das alianças transnacionais contemporâneas". Estudos da dupla - cujo foco não é a transnacionalização de grupos de origem rural, mas a constituição de movimentos transnacionais - aproximam classe, identidade e ideologia como elementos que unem ou afastam os movimentos transnacionais.

Porém, resta ainda compreender como coletivos da mesma origem nacional e que articulam grupos rurais semelhantes - e por vezes superpostos, ainda que não idênticos -, constroem trajetórias transnacionais específicas. Isso requer, conforme argumentou-se nesse artigo, compreender a diversidade das questões priorizadas e as maneiras encontradas para se inserir nos debates internacionais, por vezes questionando-os, por vezes incorporando-os como ferramentas para disputas nacionais em curso.

As características dessas organizações são relevantes para que se compreenda as diferentes controvérsias nas quais se engajam e engajaram. Se o argumento sobre a composição dos atores por meio de suas relações está correto, então ser associado a uma ou outra organização, estruturar-se internamente de uma ou outra maneira, defender uma ou outra bandeira política, importa na medida em que conforma os grupos e molda suas práticas e relações. Isso nos ajuda a explicar as diferentes controvérsias nas quais cada grupo se engajou. As associa- 
ções anteriores facilitam novas associações e dificultam outras - por exemplo, facilitaram que a Contag mantivesse relações com outros sindicatos, se afiliasse à UITA e contribuísse para a criação da Coprofam; e facilitaram que o MPA se associasse à Via Campesina e à Cloc, dificultando o inverso. Entre essas articulações circulam também elementos não estritamente racionais - afetos, sentimentos e solidariedades - que são levados pelos atores às suas interações, mas que também são produzidos ao longo de interações entre atores situados em locais diferentes. Isso gera impactos nas suas formas de identificação e em seus posicionamentos políticos sempre enredados, processuais e contestados (Featherstone, 2008).

A consolidação da inserção transnacional dos movimentos estudados ocorreu quando as organizações:

a. formularam uma plataforma política própria, isto é, temas que pretendiam levar para os debates transnacionais ou sobre os quais pretendiam incidir, incluindo formulações sobre quais eram as disputas em questão e qual era sua contribuição para elas; e

b. conseguiram ter papel em construir e manter as organizações transnacionais com as quais se articulam. Isso ocorreu, nos casos aqui apresentados, quando as organizações formularam (ou foram relevantes para a formulação de) maneiras próprias de agregar elementos. Quando fazem isso, elas se tornam centrais para as redes que estabelecem e sua transnacionalização muda de perfil: constroem mais articulações, independentes; carregam suas formulações para essas interações e são levadas por elas a novas articulações, de modo que conexões prévias passam a criar condições para que novos laços se estabeleçam. Dessa maneira, produzem uma dinâmica transnacional mais intensa e com maiores efeitos sobre as próprias organizações, consolidando sua ação transnacional.

As filiações de movimentos nacionais a redes internacionais não foram, por si só, suficientes para determinar quais seriam as questões que constituiriam sua ação transnacional. Ao contrário, entre as possibilidades que o pertencimento a cada rede ou organização internacional abre, de maneira contingencial, cada organização fez escolhas, priorizou atividades e estabeleceu associações específicas. Se várias tentativas foram frustradas, outras prosperaram e geraram novas associações. 
As controvérsias - o conteúdo da transnacionalização - são diferentes porque os elementos reunidos por cada grupo, e as maneiras como eles são reunidos, são diferentes. Isso fica evidente quando se trata de controvérsias distintas, mas vale também para as situações em que ambas as organizações se engajam nas mesmas controvérsias. Nos casos aqui estudados, sobrepõem-se aquelas sobre modelos de agricultura, sobre a entrada das mulheres nos debates transnacionais e sobre o comércio internacional. Associações que emergem em cada uma delas são diferentes, mesmo quando se trata de uma mesma disputa. Isso decorre de que, para se engajar em uma controvérsia, é preciso refletir sobre ela, encontrar meios de compreendê-la e representá-la no interior das redes de sentido das práticas compartilhadas pelo grupo.

(Recebido para publicação em 9 de janeiro de 2019) (Reapresentado em 20 de dezembro de 2020)

(Reapresentado em 7 de maio de 2020) (Aprovado para publicação em 12 de outubro de 2020)

\section{NOTAS}

1. Em 2015, a Contag passou por um processo de "dissociação sindical", separando a representação de assalariados e assalariadas rurais daquela dos agricultores e agricultoras familiares. Foi criada a Confederação Nacional dos Trabalhadores Assalariados e Assalariadas Rurais (Contar) e a Contag manteve a sigla, mas passou a responder por Confederação Nacional dos Trabalhadores Rurais Agricultores e Agricultoras Familiares (Picolotto, 2018). Emprego, neste artigo, a denominação anterior porque foi a utilizada na maior parte do período aqui estudado.

2. Entrevistas concedidas à autora pelo assessor internacional da Contag, em 23 de novembro de 2016, e por seu vice-presidente em 9 de março de 2018.

3. O termo "plebiscito popular" foi utilizado pela Campanha Contra a ALCA pelo fato de não ter sido um plebiscito oficial, promovido pelo Estado, e para destacar o vínculo entre as instituições que o promoveram e as classes populares.

4. Em 2003, informe técnico do Fida Mercosur identificava os conceitos usados no Brasil, Paraguai, Argentina e Uruguai, bem como o perfil das políticas para a área, indicando que a agricultura familiar ainda não era termo corrente (FIDA Mercosur, 2003).

5. Entrevista concedida à autora por militante do MPA no dia $1^{\circ}$ de abril de 2017.

6. Para uma sistematização das periodizações do MST ver Rubbo (2013).

7. O autor define territorialização como o processo de criação de ocupações e assentamentos, entendendo-os como espaços nos quais "o campesinato se recria e reproduz a luta pela terra mediante a formação de um movimento camponês" (Fernandes, 2010:163). 


\section{REFERÊNCIAS}

ABERS, Rebecca; SERAFIM, Lizandra; TATAGIBA, Luciana. (2014), “Repertórios de interação estado-sociedade em um Estado heterogêneo: a experiência na Era Lula”. DADOS - Revista de Ciências Sociais, vol. 57, n 2, pp. 325-357.

ABRAMOVAY, Miriam; SILVA, Rosicleide. (2000), “As relações de gênero na Confederação Nacional de Trabalhadores Rurais (Contag)". In: M. I. B. Rocha (org.), Trabalho e gênero: mudanças, permanências e desafios. São Paulo: Ed. 34, pp. 347-366.

ALONSO, Angela. (2009), "A teoria dos movimentos sociais: um balanço do debate". Lua Nova, $\mathrm{n}^{\circ} 76, \mathrm{pp} .49-86$.

ALVAREZ, Sonia E. (2000), “A globalização dos feminismos latino-americanos”. In: S. Alvarez; E. Dagnino; A. Escobar (orgs.), Cultura e política nos movimentos sociais latino-americanos. Novas leituras. Belo Horizonte: Editora UFMG, pp. 383-426.

(2014), "Para além da sociedade civil: reflexões sobre o campo feminista". Cadernos Pagu, $n^{\circ} 43$, pp. 13-56.

ALVAREZ, Sonia E.; COSTA, Claudia L.; FELIU, Verónica; HESTER, Rebeca; KLAHN, Norma; THAYER, Millie. (2014), Translocalities/translocalidades. Feminist politics of translation in the Latin/a Americas. Durham and London: Duke University Press.

BERGAMASCO, Sonia Maria; DELGADO, Guilherme Costa (orgs.). (2017), Agricultura familiar brasileira: desafios e perspectivas de futuro. Brasília: Sead.

BERRÓN, Gonzalo. (2007), “De la lucha contra el Alca a la 'integración de los pueblos': movimientos sociales y procesos de integración". Res Diplomática, vol. 1, pp. 6-23.

BORRAS Jr., Saturnino; EDELMAN, Marc. (2016), Political dynamics of transnational agrarian movements. Nova Scotia: Fernwood Publishing.

BORRAS Jr., Saturnino; EDELMAN, Marc; KAY, Cristóbal. (2008), Transnational agrarian movements confronting globalization. West Sussex: Blackwell.

BRINGEL, Breno. (2010), "Ativismo transnacional, o estudo dos movimentos sociais e as novas geografias pós-coloniais". Estudos de Sociologia, vol. 16, n² 2, pp. 185-215.

; FALERO, Alfredo. (2008), "Redes transnacionais de movimentos sociais na América Latina e o desafio de uma nova construção socioterritorial". CRH [online], vol. 21, no 53 , pp. 267-86.

BRINGEL, Breno; VIEIRA, Flávia Braga. (2015), “Movimientos internacionalistas y prácticas de cooperación Sur-Sur: brigadas y experiencias formativas del movimiento de los sin tierra de Brasil y la Via Campesina". Revista Española de Desarrollo y Cooperación, vol. 36 , pp. $65-80$.

CADONÁ, Célio Valdemar. (2004), Movimento dos Pequenos Agricultores - MPA: o novo nasce nas estradas. Dissertação (Mestrado em Educação nas Ciências), Universidade Regional do Noroeste do Estado do Rio Grande do Sul, Rio Grande do Sul.

CALHOUN, Craig. (1995), "NNew social movements' of the early nineteenth century". In M. Traugott (ed.), Repertoires and cycles of collective action. Durham: Duke University Press, pp. 173-216. 
CAMPOS, Antônio Valmor de. (2007), Milho crioulo: Sementes de vida. Frederico Wesphalen, RS: Editora URI.

CARTER, Miguel. (2010), Combatendo a desigualdade social. O MST e a Reforma Agrária no Brasil. São Paulo: Ed. Unesp.

CARVALHO, Horacio Martins. (2005), O campesinato no século XXI - Possibilidades e condicionantes para o desenvolvimento do campesinato no Brasil. Petrópolis: Vozes.

CARVALHO, Priscila Delgado de. (2011), Ação coletiva transnacional e Mercosul: organizações da sociedade civil do Brasil e do Paraguai na Reaf. Dissertação (Mestrado em Ciência Política), Universidade de Brasília, Distrito Federal.

CARVALHO, Priscila Delgado de. (2020), "Além da forma-movimento: compilações do Movimento dos Pequenos Agricultores". Revista Brasileira de Sociologia, vol. 8, n 18, pp. 83-106.

CONGRESSO NACIONAL DOS LAVRADORES E TRABALHADORES AGRÍCOLAS SOBRE O CARÁTER DA REFORMA AGRÁRIA. (1961), Declaração. Disponível em: https:// www.marxists.org/portugues/tematica/1961/11/17.html.

CONTAG. (1973), Anais do 20 Congresso Nacional dos Trabalhadores Rurais. Brasília: Contag.

CONTAG. (1979), Anais do $3^{\circ}$ Congresso Nacional dos Trabalhadores Rurais. Brasília: Contag.

CONTAG. (1985), Anais do $4^{\circ}$ Congresso Nacional dos Trabalhadores Rurais. Brasília: Contag.

CONTAG. (1998), Anais do $7^{\circ}$ Congresso Nacional dos Trabalhadores e Trabalhadoras Rurais. Brasília: Contag.

COSTA, Claudia de Lima. (2014), "Feminist theories, transnational translations, and cultural mediations". In: S. Alvarez et al., Translocalites/translocalidades. Durham and London: Duke University Press, pp. 133-148

COSTA, Hermes Augusto. (2005), “O sindicalismo, a política internacional e a CUT". Lua Nova, $\mathrm{n}^{\circ} 64$, pp. 129-152.

COSTA, Maria José. (2014), Construção do Plano Camponês: experiências de políticas públicas de desenvolvimento para o campo brasileiro. Dissertação (Mestrado em Geografia), Universidade Estadual Paulista, São Paulo.

DELLA PORTA, Donatella; TARROW, Sidney. (2005), Transnational protest and global activism. Oxford: Rowman \& Littlefield Publishers.

DESAI, Manisha. (2009), Gender and the politics of possibilities. Lanham: Rowman \& Littefield Publishers.

DESMARAIS, Annette Aurélie. (2007), La Via Campesina: globalization and the power of the peasants. Halifax and Winnipeg, Fernwood Publishing.

EDELMAN, Marc. (2012), "Linking the rights of peasants to the right to food in the United Nations". Law, Culture and the Humanities, vol. 10, n 2, pp. 196-211.

EVANS, Peter. (2015), "Movimentos nacionais de trabalhadores e conexões transnacionais: a evolução da arquitetura das forças sociais do trabalho no neoliberalismo". CRH [online], vol. $28, \mathrm{n}^{\circ} 75$, pp. $457-478$. 
FAVARETO, Arilson. (2006), "Agricultores, trabalhadores: os trinta anos do novo sindicalismo rural no Brasil”. Revista Brasileira de Ciências Sociais, vol. 21, nº 62, pp. 27-44.

FEATHERSTONE, David. (2008), Resistance, space and political identities: The Making of Counter-Global Networks. West Sussex: Wiley-Blackwell.

FERNANDES, Bernardo Mançano; MEDEIROS, Leonilde Sérvolo; PAULILO, Maria Ignez. (2009), Lutas camponesas contemporâneas: condições, dilemas e conquistas. Vol. 1: o campesinato como sujeito político nas décadas de 1950 a 1980. São Paulo e Brasília: Editora Unesp e Nead.

FERNANDES, Bernardo M. (2010), "Formação e territorialização do MST no Brasil". In: M. Carter (ed.), Combatendo a desigualdade social. O MST e a reforma agrária no Brasil. São Paulo: Ed. Unesp, pp. 161-197.

FIDA Mercosur. (2003), Políticas de apoyo a la agricultura familiar en el Mercosur Preliminar. Montevideo.

FLEURY, Lorena Cândido. (2014), "O conflito em torno da construção da usina hidrelétrica de Belo Monte sob o idioma da coprodução". Anais do $38^{\circ}$ Encontro Anual da ANPOCS. Caxambu: ANPOCS.

IBGE. (2010), Censo Demográfico 2010. Brasília, IBGE. Disponível em: https:/ / censo2010.ibge. gov.br/resultados.html. Acesso em: 17 dez. 2020.

KECK, Margaret E.; SIKKINK, Kathryn. (1998), Activists beyond borders. Ithaca: Cornell University Press.

LATOUR, Bruno. (2008), Reensamblar lo social. Una introducción a la teoría del actor-red. Buenos Aires: Manantial.

LAW, John. (2004), After method. Mess in social science research. New York: Routledge.

MCKEON, Nora. (2015), Food security governance: empowering communities, regulating corporations. New York: Routledge.

MEDEIROS, Leonilde Sérvolo de. (1989), História dos movimentos sociais no campo. Rio de Janeiro: FASE.

. (1997), "Trabalhadores rurais, agricultura familiar e organização sindical”. Revista São Paulo em Perspectiva, vol. 11, n 2, pp. 65-72.

. (2014), "O sindicalismo rural nas últimas décadas: mudanças e permanências". In: R. V. de Oliveira; M. A. Bridi; M. Ferrraz (eds.), O sindicalismo na era Lula: paradoxos, perspectivas e olhares. Belo Horizonte: Fino Traço Editora, pp. 247-282.

MPA. (2010), Cartilha de resultados do V Congresso da CLOC. Brasília: MPA.

(2015), Internacionalismo y solidaridad entre los pueblos! Cooperación campesina un lazo de reciprocidad. Brasília: MPA.

MST. (2001), "Somente lutando outro mundo é possível”. Jornal Sem Terra, Ano XIX, n² 207, p. 12. Disponível em: http:/ /docvirt.com/Hotpage/Hotpage.aspx?bib=HEMEROLT\&pag fis=4377\&url=http:/ / docvirt.com/docreader.net\#. Acesso em: 17 dez. 2020. 
NIEMEYER, Carolina Burle de. (2014), Movimentos sociais como produtores de conhecimento: a soberania alimentar no Movimento de Pequenos Agricultores (MPA). Tese (Doutorado em Ciências Sociais), Universidade do Estado do Rio de Janeiro, Rio de Janeiro.

NIERDELE, Paulo André. (2016), “A construção da reunião especializada sobre agricultura familiar (Reaf) do Mercosul: sociogênese de uma plataforma de diálogos entre governos e movimentos sociais". Estudos Sociedade e Agricultura, vol. 24, pp. 539-603.

NYE, Joseph A; KEOHANE, Robert. (1971), “Transnational relations and world politics: an introduction". International Organization, vol. 25, n 3, pp. 329-349.

OIT. (1997), Trade union action against child labour - brazilian experience. Brasília: OIT.

. (2015), Dar una voz a los trabajadores rurales. Estudio general sobre los instrumentos relativos al derecho de asociación y las organizaciones de trabajadores rurales. Genebra: OIT.

PALMEIRA, Moacir. (1985), “A diversidade da luta no campo: luta camponesa e diferenciação do campesinato". In: P. Vanilda (org.), Igreja e questão agrária. São Paulo: Edições Loyola.

PENNA, Camila. (2015), Conexões e controvérsias no Incra de Marabá. O Estado como um ator heterogêneo. Rio de Janeiro: Garamond.

PICOLOTTO, Everton Lazzaretti. (2015), "Os atores da construção da categoria agricultura familiar no Brasil". Revista de Economia e Sociologia Rural, n 52, sup. 1, pp. 63-84.

(2018), "Pluralidade sindical no campo? Agricultores familiares e assalariados rurais em um cenário de disputas". Lua Nova, vol. 104, pp. 201-238.

PLEYERS, Geoffrey. (2010), Alter-globalization. becoming actors in the global age. Cambridge: Polity.

RICARD, Jan Frans. (2010), “Movimento sindical internacional”. In: Dicionário: trabalho, profissão e condição docente. Belo Horizonte: UFMG/Faculdade de Educação.

RICCI, Rudá. (1999), Terra de ninguém. Representação sindical rural no Brasil. Campinas: Editora da Unicamp.

. (2009), "A maior estrutura sindical do Brasil: papel do sindicalismo de trabalhadores rurais no pós-64". In: B. M. Fernandes; L. S. de Medeiros; M. I. Paulilo (orgs.), Lutas camponesas contemporâneas: condições, dilemas e conquistas. Vol. 2: a diversidade das formas das lutas no campo. São Paulo: Ed. Unesp, pp. 321-368.

RODRÍGUEZ-GIRALT, Israel. (2011), "Social movements as actor-networks: prospects for a symmetrical approach to Doñana's environmentalist protests". Convergencia, vol. 18, $\mathrm{n}^{\mathrm{o}} 56$, pp. 13-35.

ROSA, Marcelo Carvalho. (2010), "Para além do MST: o impacto nos movimentos sociais brasileiros". In: M. Carter (ed.), Combatendo a desigualdade social. O MST e a reforma agrária no Brasil. São Paulo: Ed. Unesp.

(2015), "A journey with the Movimento dos Trabalhadores Rurais e Sem-Terra (MST) across Brazil and on to South Africa". Études Rurales, n 196, pp. 43-56.

RUBBO, Deni Ireneu Alfaro. (2013), Campesinos cosmopolitas: um estudo sobre a atuação política internacionalista do MST na América Latina. Dissertação (Mestrado em Sociologia), Universidade de São Paulo, São Paulo.

SASSEN, Saskia. (2007), A sociology of globalization. New York: W. W. Norton \& Company. 
SCOTT, James C. (1990), Domination and the arts of resistance: hidden scripts. New Heaven: Yale University Press.

SEVILLA GUZMÁN, Eduardo; MOLINA, Manuel. (2013), Sobre a evolução do conceito de campesinato. São Paulo: Expressão Popular.

SIGAUD, Lygia; ERNANDEZ, Marcelo; ROSA, Marcelo. (2010), Ocupações e acampamentos. Rio de Janeiro: Garamond.

SILVA, Berenice. (2008), A Marcha das Margaridas: resistências e permanências. Dissertação (Mestrado em Sociologia). Universidade de Brasília, Brasília.

SILVA, Marcelo Leal Teles (org.). (2016), Projeto Alimergia. Candiota: Instituto Cultural Padre Josimo.

SILVA, Suylan de Almeida (2008), "Ganhamos a batalha, mas não a guerra": a visão da campanha nacional contra a Alca sobre a não-assinatura do acordo. Tese (Doutorado em Sociologia), Universidade de Brasília, Distrito Federal.

SILVA, Valter Israel. (2009), Caminhos da afirmação camponesa. Elementos para um plano camponês. Tupanciretã, RS: Instituto Cultural Padre Josimo.

STÉDILE, João Pedro. (2007), “Prefácio à edição brasileira. A história da formação da Via Campesina Internacional". In: A. A. Desmarais (ed.), Via Campesina. São Paulo: Expressão Popular.

TARROW, Sidney. (2005), New transnational activism. Cambridge: Cambridge University Press.

TAVARES, Jozelita; COSTA, Josineide; FAGUNDES, Marli. (2016), Diversidade produtiva das mulheres do MPA. São Paulo: Expressão Popular.

TAVARES, Ricardo. (1992), CONTAG, da ditadura à transição - memória social e construção política do "campesinato". Dissertação (Mestrado em Sociologia). Instituto Universitário de Pesquisa do Rio de Janeiro, Rio de Janeiro.

THAYER, Millie. (2010), Making transnational feminism: rural women, NGO activists, and northern donors in Brazil. New York/Cambridge: Routledge.

THOMPSON, Edward. (1987), A formação da classe operária inglesa. Rio de Janeiro: Paz e Terra, v. 1.

VENTURINI, Tommaso. (2010), "Diving in Magma. How to explore controversies with actor network theory". Public Understanding of Science, vol. 19, nº 3, pp. 258-273.

VON BÜLOW, Marisa. (2014), A batalha do livre comércio. São Paulo: Editora Unesp.

VON BÜLOW, Marisa; CARVALHO, Priscila D. (2012), “Entre o nacional e o transnacional - O caso das organizações da agricultura familiar no Mercosul". In: M. da G. GOHN; B. BRINGEL (eds.), Movimentos sociais na era global. Petrópolis: Vozes, pp. 229-246.

WANDERLEY, Maria. (2003), "Agricultura familiar e campesinato: rupturas e continuidade". Estudos Sociedade e Agricultura, vol. 11, nº 2, pp. 42-61.

WATERMAN, Peter. (2001), Globalization, social movements and the new Internationalisms. London/Washington: Continuum.

WELCH, Clifford A. (2010), A semente foi plantada: as raízes paulistas do movimento sindical camponês no Brasil, 1924-1964. São Paulo: Expressão Popular. 


\section{RESUMO}

\section{Controvérsias e a Produção do Transnacional: Os Casos da Contag e do MPA}

$\mathrm{O}$ artigo analisa a ação transnacional de organizações de origem nacional por meio das controvérsias - isto é, das disputas nas quais esses grupos se envolvem - observando suas transformações ao longo do tempo e a existência de disputas simultâneas. Apresenta uma definição de transnacionalização que enfatiza o esforço de grupos nacionais para se tornarem parte de disputas que envolvem enquadramentos discursivos e práticas políticas transnacionais, argumentando que a transnacionalização consolida-se quando são capazes de: a) formular uma plataforma política própria que aporte temas ou análises aos debates transnacionais; e b) atuar no estabelecimento ou na permanência das organizações e redes transnacionais às quais se articulam. Isso ocorre quando contribuem com maneiras específicas de manter elementos reunidos que as permitem construir novas articulações e produzir efeitos sobre as próprias organizações. Os argumentos são embasados na análise da transnacionalização de duas organizações rurais brasileiras: a Confederação Nacional dos Trabalhadores na Agricultura (Contag) e o Movimento dos Pequenos Agricultores (MPA).

Palavras-chave: transnacionalização; campesinato; agricultura familiar; soberania alimentar; controvérsias

\section{ABSTRACT \\ Controversies and the Production of the Transnational: The Cases of the National Confederation of Agricultural Workers (Contag) and the Small Farmers Movement (MPA).}

This article analyzes the transnational action of nationally-based organizations through controversies - that is, the disputes in which these groups engage. It discusses how controversies evolve over time, as well as the existence of simultaneous disputes. This article presents a definition of transnationalization that emphasizes the effort of national groups to become part of disputes around discursive frameworks and transnational political practices. Stable transnational ties are built when these groups: a) formulate their own political platform and provide content for transnational debates; and b) contribute to the creation or continuity of transnational organizations and networks. This occurs when they provide specific ways of holding elements together that allow them to build new connections and to produce effects on the networks. Conclusions are based on the analysis of the transnational action of two Brazilian rural organizations: the National Confederation of Agricultural Workers (Contag) and the Small Farmers Movement (MPA).

Keywords: transnationalization; peasantry; family farming; food sovereignty; controversies 


\section{RÉSUMÉ \\ Controverses et Production de la Société Transnationale: Les Cas de la Contag et du MPA}

L'article analyse la transnationalisation des associations d'origine nationale à travers les controverses - c'est-à-dire les conflits dans lesquels ces groupes sont impliqués - en observant leurs transformations dans le temps et l'existence de conflits simultanés. On présente une définition de la transnationalisation qui met l'accent sur l'effort des groupes nationaux pour faire partie des conflits impliquant des cadres discursifs et des pratiques politiques transnationales, en faisant valoir que la transnationalisation est consolidée lorsqu'ils sont capables: a) de formuler leur propre plateforme politique qui apporte des thèmes ou des analyses de débats transnationaux; et b) d'agir dans l'établissement ou la permanence des associations et réseaux transnationaux auxquels ils sont liés. Cela se produit lorsqu'ils contribuent à la mise-en-place de moyens spécifiques de garder les éléments ensembles qui leur permettent de construire de nouvelles articulations et de produire des effets sur les organisations elles-mêmes. Les arguments sont basés sur l'analyse de la transnationalisation de deux organisations rurales brésiliennes: la Confederação Nacional dos Trabalhadores na Agricultura (Contag) et le Movimento dos Pequenos Agricultores (MPA).

Mots-clés: transnationalisation; paysannerie; agriculture familiale; souveraineté alimentaire; controverses

\section{RESUMEN}

\section{Controversias y la Producción de lo Transnacional: Los Casos de la Contag y del MPA}

El artículo analiza la transnacionalización de organizaciones de origen nacional por medio de las controversias - es decir, de las disputas en las cuales esos grupos se involucran-observando sus transformaciones a lo largo del tiempo y la existencia de disputas simultáneas. Se presenta una definición de transnacionalización que enfatiza el esfuerzo de grupos nacionales para tornarse parte de disputas que envuelven marcos discursivos y prácticas políticas transnacionales, argumentando que la transnacionalización se consolida cuando son capaces de: a) formular una plataforma política propia que aporte temas o análisis a los debates transnacionales; y b) actuar en el estabelecimiento o en la permanencia de las organizaciones y redes transnacionales a las cuales se articulan. Eso ocurre cuando contribuyen con maneras específicas de mantener elementos reunidos que permiten construir nuevas articulaciones y producir efectos sobre las proprias organizaciones. Los argumentos son basados en el análisis de la transnacionalización de dos organizaciones rurales brasileñas: la Confederación Nacional de los Trabajadores en la Agricultura (Contag) y el Movimiento dos Pequeños Agricultores (MPA).

Palabras clave: transnacionalización; campesinado; agricultura familiar; soberanía alimentaria; controversias 